\title{
Intermittent Hypoxia Up-Regulates CCL2, RETN, and TNF $\alpha$ mRNAs in Adipocytes via Down-regulation of miR-452
}

\author{
Tomoko Uchiyama ${ }^{1,2}$, Asako Itaya-Hironaka ${ }^{1}$, Akiyo Yamauchi ${ }^{1}$, Mai Makino ${ }^{1}$, \\ Sumiyo Sakuramoto-Tsuchida ${ }^{1}$, Ryogo Shobatake ${ }^{1}{ }^{[}$, Hiroyo Ota ${ }^{1,3}$, Maiko Takeda ${ }^{2,4}$, \\ Chiho Ohbayashi ${ }^{2}$ and Shin Takasawa ${ }^{1, *}$ (1)
}

1 Department of Biochemistry, Nara Medical University, 840 Shijo-cho, Kashihara, Nara 634-8521, Japan; uchiyama0403@naramed-u.ac.jp (T.U.); iasako@naramed-u.ac.jp (A.I.-H.); yamauchi@naramed-u.ac.jp (A.Y.); m.makino@naramed-u.ac.jp (M.M.); ssumiyo@naramed-u.ac.jp (S.S.-T.); rshobatake@naramed-u.ac.jp (R.S.); hiroyon@naramed-u.ac.jp (H.O.)

2 Department of Diagnostic Pathology, Nara Medical University, 840 Shijo-cho, Kashihara, Nara 634-8522, Japan; maikot@naramed-u.ac.jp (M.T.); ohbayashi@naramed-u.ac.jp (C.O.)

3 Second Department of Internal Medicine, Nara Medical University, 840 Shijo-cho, Kashihara, Nara 634-8522, Japan

4 Department of Laboratory Medicine and Pathology, National Hospital Organization Kinki-chuo Chest Medical Center, 1180 Nagasone-cho, Kita-ku, Sakai, Osaka 591-8025, Japan

* Correspondence: shintksw@naramed-u.ac.jp; Tel.: +81-744-22-3051 (ext. 2227); Fax: +81-744-24-9525

Received: 23 March 2019; Accepted: 19 April 2019; Published: 22 April 2019

\begin{abstract}
Sleep apnea syndrome (SAS), characterized by recurrent episodes of oxygen desaturation and reoxygenation (intermittent hypoxia $[\mathrm{IH}]$ ), is a risk factor for insulin resistance. Recently, $\mathrm{IH}$ is considered to independently cause adipose tissue inflammation/dysfunction, leading to worsening insulin resistance; however, the detailed mechanism remains unknown. We exposed mouse 3T3-L1 and human SW872 adipocytes to experimental IH or normoxia for $24 \mathrm{~h}$, and analyzed mRNA expression of several adipokines. We found that the mRNA levels of RETN, TNF $\alpha$, and CCL2 in SW872 and 3T3-L1 adipocytes were significantly increased by IH, whereas the promoter activities of these genes were not increased. A target mRNA search of microRNA (miR)s revealed that all human mRNAs have a potential target sequence for miR-452. The miR-452 level of IH-treated cells was significantly decreased compared to normoxia-treated cells. MiR-452 mimic and non-specific control RNA (miR-452 mimic NC) were introduced into SW872 cells, and the IH-induced up-regulation of the genes was abolished by introduction of the miR-452 mimic but not by the miR-452 mimic NC. These results indicate that IH stress down-regulates the miR-452 in adipocytes, resulting in increased levels of RETN, TNF $\alpha$, and CCL2 mRNAs, leading to insulin resistance in SAS patients.
\end{abstract}

Keywords: adipokine; intermittent hypoxia; microRNA; sleep apnea syndrome

\section{Introduction}

Sleep apnea syndrome (SAS) is a highly prevalent disease characterized by repetitive episodes of pharyngeal airway narrowing or obstruction during sleep, leading to apnea and hypopnea, often accompanied by a decrease in oxygen saturation [1]. It is a disorder affecting about $14-24 \%$ in men and 5-9\% in women [2,3]. Accumulating evidence suggests that recurrent short cycles of oxygen desaturation followed by rapid reoxygenation (intermittent hypoxia [IH]), which are typical features of SAS, contribute to the development of impaired glucose tolerance/insulin resistance [4-6]. This relationship is considered to be irrelevant to the degree of obesity [7-9]. In addition to $\mathrm{IH}$, 
several pathogenic mechanisms, such as sympathetic nervous system hyperactivity, oxidative stress, vascular endothelial dysfunction, and activation of the inflammatory cytokines, are all potential contributors to insulin resistance [10]. However, the detailed mechanisms by which IH induces insulin resistance in SAS patients are not well established. We have investigated how IH induces impaired insulin secretion/insulin resistance using pancreatic $\beta$ cells, hepatocytes, and neuronal cells. We have reported that IH stress influences pancreatic $\beta$ cell proliferation/dysfunction, hepatocytes proliferation/dysfunction, and synthesis of anorexigenic peptides in neuronal cells, which may lead to aggravate insulin resistance/type 2 diabetes [1,11,12].

Adipose tissue, complex tissue composed of preadipocytes, adipocytes, and stromal vascular cells, is one of the representative organs that contribute to worsening insulin resistance by inflammation and subsequent dysfunction [13]. Adipokines are hormones expressed and secreted from adipocytes in response to the systemic nutritional status, and some of which induce macrophage infiltration and inflammatory cytokine secretion $[14,15]$. Recently, it has been reported that SAS patient adipose tissues become inflamed by macrophage infiltration, inflammatory cytokines, and increased blood flow, resulting in insulin resistance $[9,16]$. Additionally, several animal studies suggested that IH induces adipocyte lipolysis, elevating plasma free fatty acid levels [17] and pro-inflammatory changes in adipose tissue independent of obesity [13], which may contribute to the pathogenesis of $\mathrm{IH}$-induced insulin resistance. However, the experimental IH-induced change of adipokines secreted from preadipocytes/adipocytes is less clear. The phase of adipocyte differentiation (preadipocytes or adipocytes) in which such significant IH-induced changes of adipokines occur remains unknown. During differentiation, preadipocytes proliferate and become mature fat cells (adipocytes), which is a process of adipogenesis $[18,19]$.

In the present study, using mouse and human adipocytes, we investigated changes of gene expression of several adipokines, synthesized/secreted from preadipocytes/adipocytes, in response to $\mathrm{IH}$, as well as their regulatory mechanisms and found the expression of resistin (Retn), tumor necrosis factor- $\alpha$ (Tnf $\alpha)$, and C-C motif chemokine ligand 2 (Ccl2) was increased by IH via down-regulation of microRNA (miR)-452.

\section{Results}

\subsection{Gene Expression of RETN, TNF $\alpha$, and CCL2 Was Increased by IH in Mouse 3T3-L1 Adipocytes and} Human SW872 Cells

We exposed mouse and human adipocytes (3T3-L1 preadipocytes, 3T3-L1 adipocytes, and SW872 cells) to normoxia or IH for $24 \mathrm{~h}$. After the treatment, we measured the mRNA levels of several adipokines (leptin [Lep], adiponectin [Adip], Retn, interleukin-6 (IL-6), TNF $\alpha$, and CCL2) by real-time reverse transcription polymerase chain reaction (RT-PCR). As shown in Figure 1, the mRNA levels of Ccl2 were significantly increased in 3T3-L1 preadipocytes $(P=0.0131)$, 3T3-L1 adipocytes $(P=0.0002)$, and SW872 cells $(P<0.0001)$. The mRNA levels of Retn and Tnfo were significantly increased in 3T3-L1 adipocytes $(P=0.0498$ and $P=0.0237$, respectively) and SW872 cells $(P=0.0257$ and $P=0.0312$, respectively). 

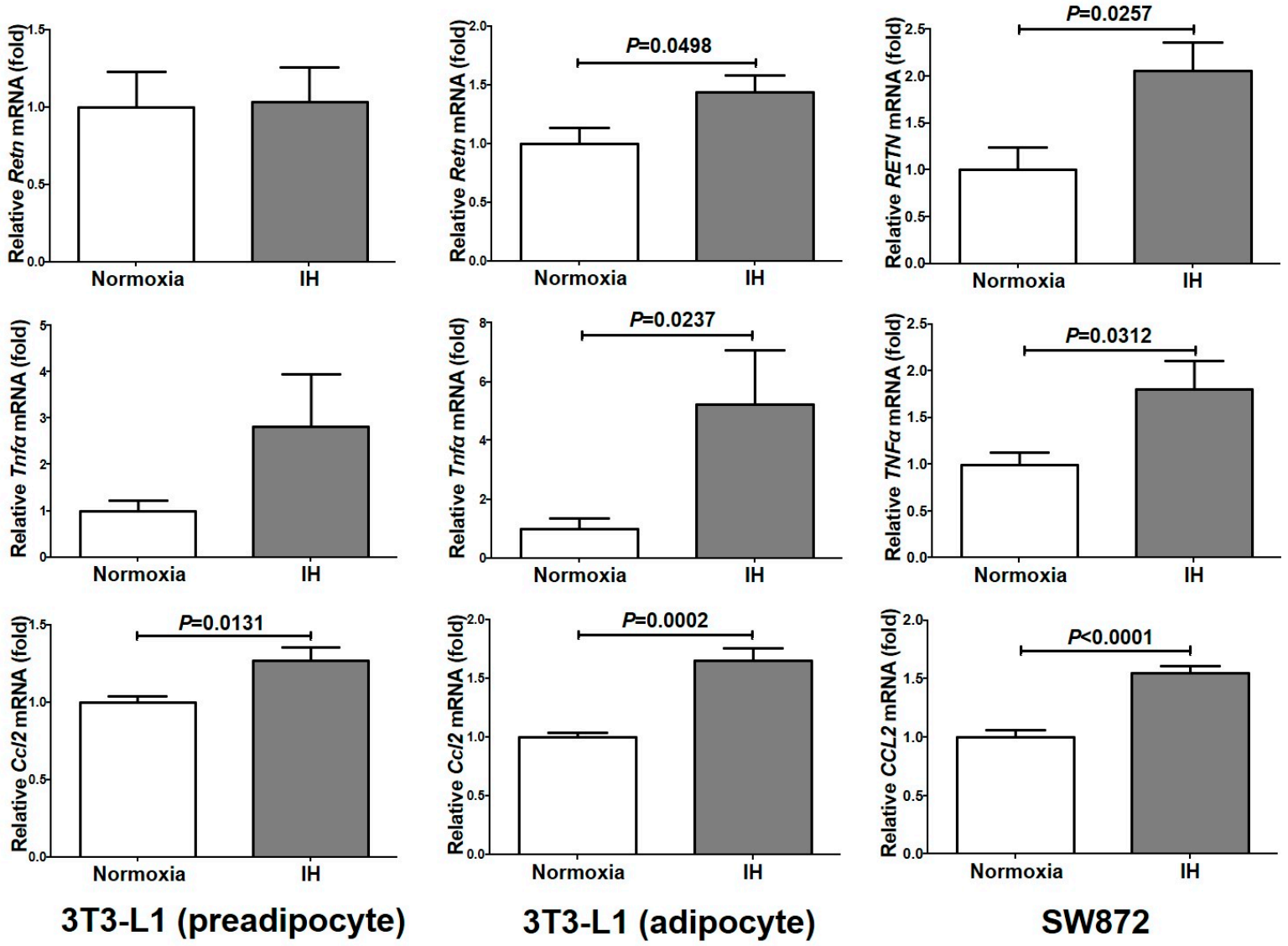

SW872

Figure 1. The mRNA levels of Retn, Tnf $\alpha$, and Ccl2 in 3T3-L1 cells (preadipocyte and adipocyte) and SW872 cells treated by normoxia or IH for $24 \mathrm{~h}$. The levels of the adipokine mRNAs were measured by real-time RT-PCR using Rig/RpS15 (in mouse) and $\beta$-actin(in human) as an endogenous control. Data is expressed as mean \pm SE for each group $(n=4)$. The statistical analyses were performed using Student's $t$-test.

On the other hand, the mRNA levels of IL-6 were significantly increased only in 3T3-L1 adipocytes $(P=0.0456)$, and unchanged in 3T3-L1 preadipocytes and SW872 cells $(P=0.3246$ and $P=0.9366$, respectively). Adip mRNA was significantly decreased in SW872 cells $(P=0.0376)$, and unchanged in either 3T3-L1 preadipocytes or adipocytes ( $P=0.5787$ and $P=0.7094$, respectively). In all the analyzed cells, the mRNA levels of Lep were not significantly changed by IH $(P=0.2359$ in 3T3-L1 preadipocytes, $P=0.4411$ in 3T3-L1 adipocytes, and $P=0.3728$ in SW872 cells) (Figure 2). Considering these results, IH stress might specifically up-regulate expression of Retn, Tnfo and Ccl2 in 3T3-L1 adipocytes and SW872 cells. 

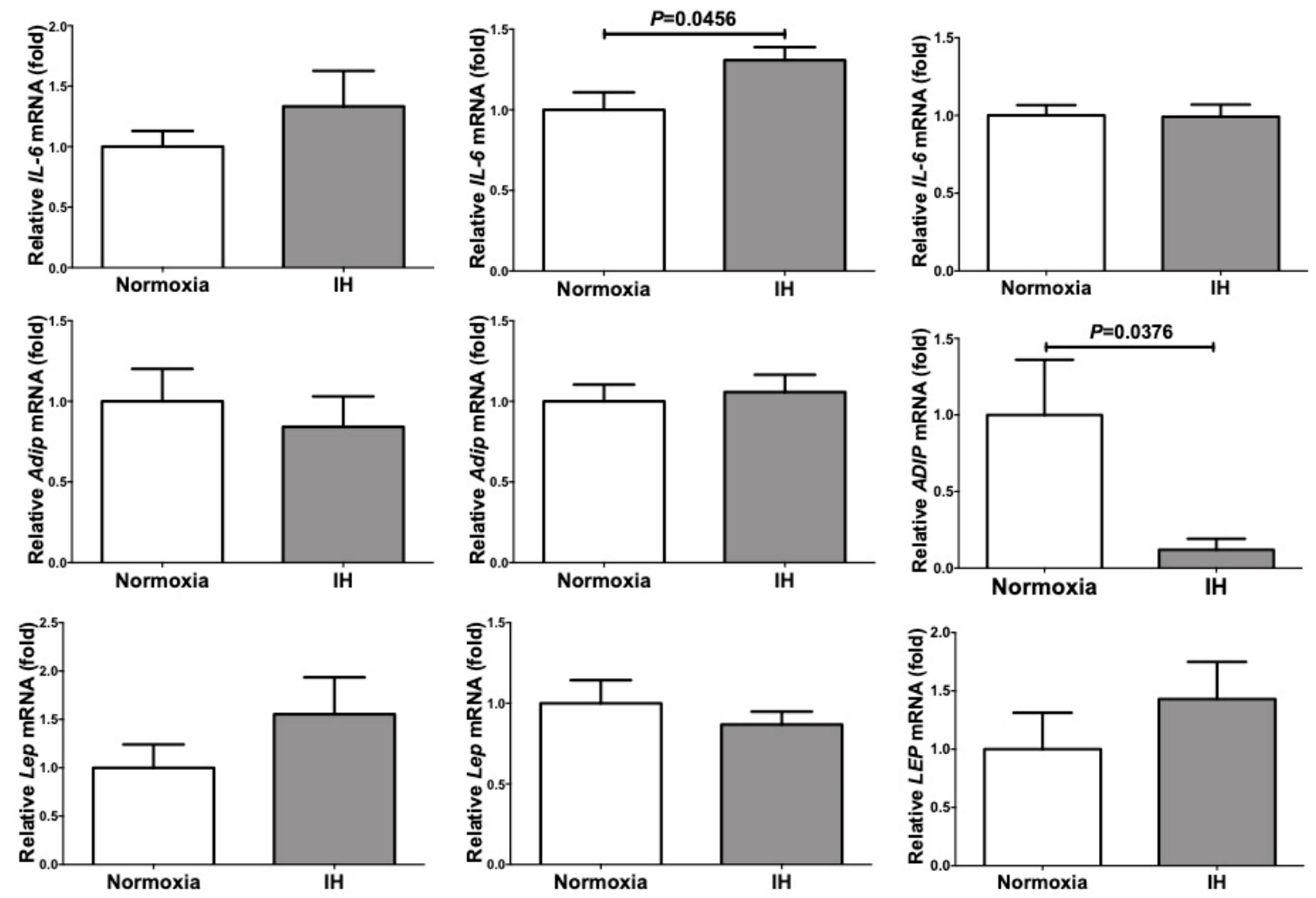

3T3-L1 (pre-adipocyte)

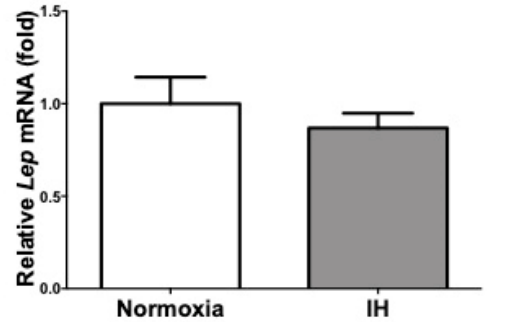

3T3-L1 (adipocyte)

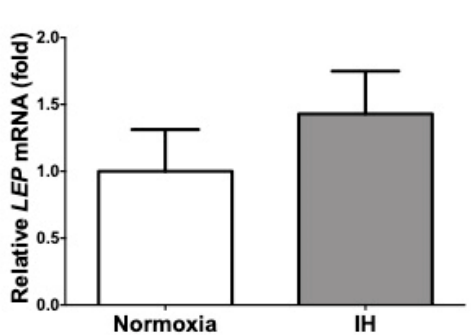

SW872

Figure 2. The mRNA levels of Il-6, Adip, and Lep in 3T3-L1 cells (pre-adipocyte and adipocyte) and SW872 cells treated by normoxia or IH for $24 \mathrm{~h}$. The levels of the adipokine mRNAs were measured by real-time RT-PCR using Rig/RpS15 (in mouse) and $\beta$-actin (in human) as an endogenous control. Data is expressed as mean \pm SE for each group $(n=4)$. The statistical analyses were performed using Student's $t$-test.

The mRNA levels of Lep, Adip and Retn in 3T3-L1 adipocytes (normoxia) were significantly increased compared to 3T3-L1 preadipocytes $(884.0 \pm 120.9$ fold $[P<0.0001], 719.2 \pm 74.96$ fold $[P<0.0001]$, and 7,032 \pm 947.5 fold $[P<0.0001]$, respectively), suggesting that these genes are expressed specifically after differentiation to adipocytes. In contrast, $C c l 2, T n f \alpha$ and $I L-6$, expressed in many different types of cell, were not significantly increased but rather decreased after differentiation from preadipocytes to adipocytes $(0.781 \pm 0.0329$ fold $[P=0.0021], 0.639 \pm 0.296$ fold $[P=0.4242]$, and $0.610 \pm 0.0664$ fold $[P=0.0233]$, respectively; Figure 3 ).

We are unable to explain the exact reason why there is a decrease in Ccl2, $\operatorname{Tn} f \alpha$, and $I L-6$ expression compared to Lep, Adip, and Retn. However, there are some clues that may help explain. (1) Tnf $\alpha$ treatment decreased Adip mRNA expression in 3T3-L1 cells [20]. (2) Tnf $\alpha$ also works as a potent negative regulator for Retn mRNA expression in 3T3-L1 cells [21,22]. (3) In addition, Tnf $\alpha$ potently induced IL-6 mRNA expression in 3T3-L1 cells [23]. (4) IL-6 works as a negative regulator for Adip mRNA expression in 3T3-L1 cells [24]. In our experiments, Tnf $\alpha$ mRNA expression was unchanged during 3T3-L1 cell differentiation. Thus, the down-regulation of Adip and Retn mRNAs by Tnf $\alpha$ and up-regulation of IL-6 mRNA by Tnf $\alpha$ did not work. As a result, up-regulation of Adip and Retn mRNAs were clearly detected. In addition, as the IL-6 expression was unchanged, down-regulation of Adip mRNA did not occur. 

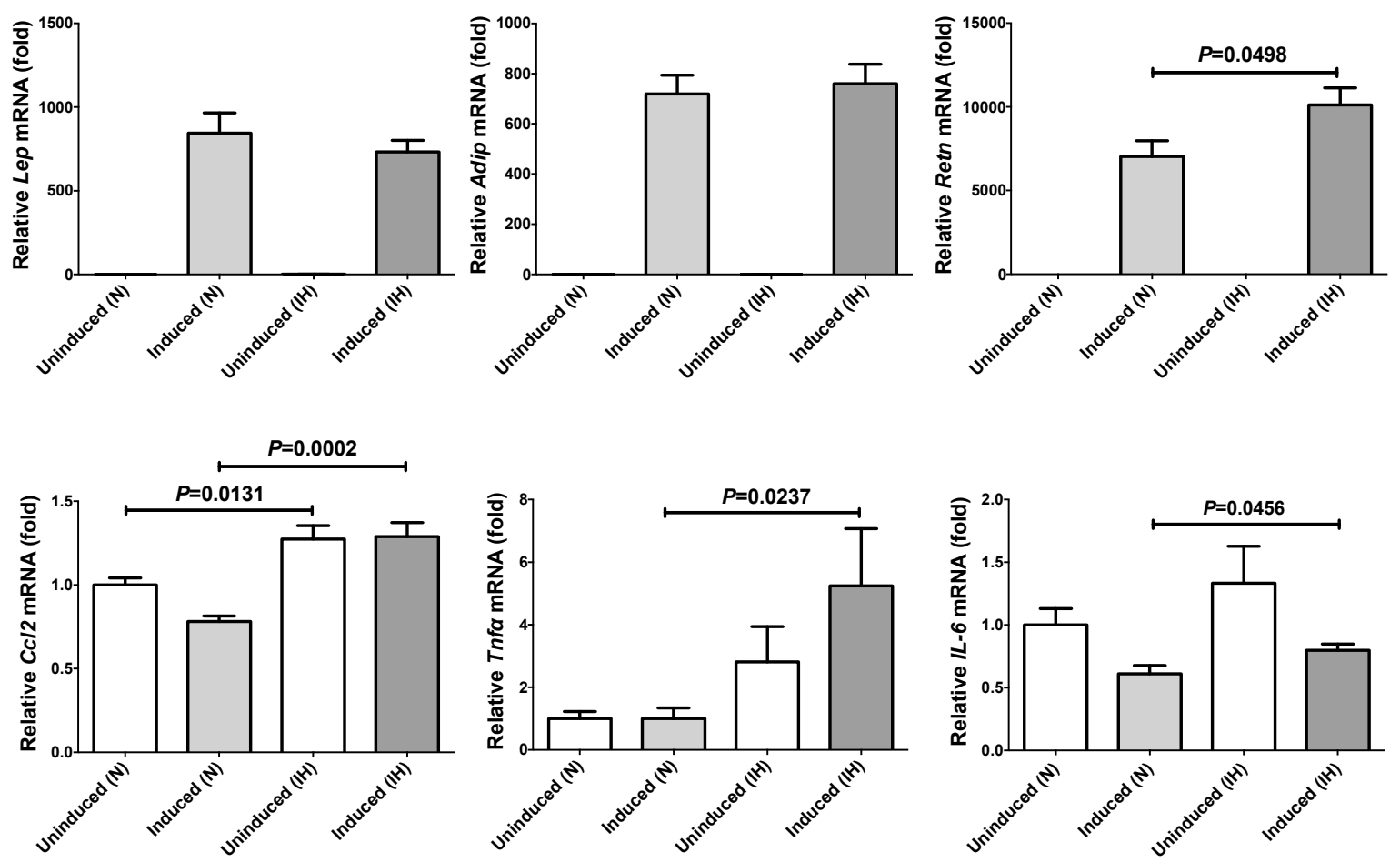

Figure 3. The mRNA levels of Lep, Adip, Retn, Ccl2, Tnf $\alpha$, and IL-6 in 3T3-L1 cells treated by normoxia or IH for $24 \mathrm{~h}$. Figure shows relative comparison of mRNA expression in 3T3-L1 preadipocytes with 3T3-L1 adipocytes. The levels of the adipokine mRNAs were measured by real-time RT-PCR using Rig/RpS15 as an endogenous control. Data are expressed as mean \pm SE for each group $(n=4)$. The statistical analyses were performed using Student's $t$-test.

We further measured RETN, TNF $\alpha$, and CCL2 protein in the culture medium by ELISA and found that the levels of RETN $(P=0.0256), \operatorname{TNF} \alpha(P=0.0215)$, and CCL2 $(P<0.0001)$ were significantly increased by IH in SW872 cells (Figure 4).
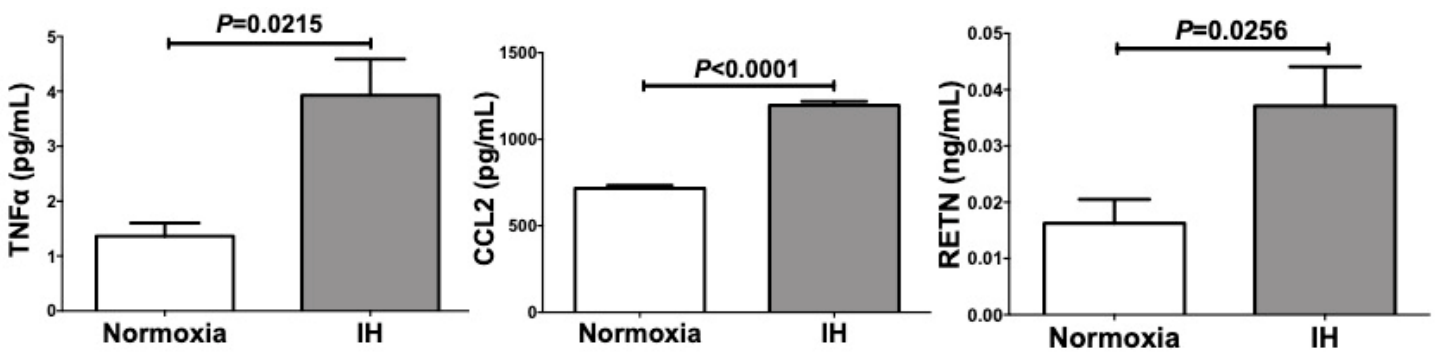

Figure 4. Concentrations of RETN, TNF $\alpha$, and CCL2 in SW872 cell culture medium were measured by ELISA. SW872 cells were treated by normoxia or IH for $24 \mathrm{~h}$. Data are expressed as means \pm SE for each group $(n=3)$.

\subsection{The Promoter Activities of RETN, TNF $\alpha$, and CCL2 Were not Increased by IH}

To determine whether the IH-induced increases in RETN, TNF $\alpha$ and CCL2 mRNAs were caused by activation of transcription, a $999 \mathrm{bp}$ fragment containing $979 \mathrm{bp}$ of the RETN promoter, a $985 \mathrm{bp}$ fragment containing $966 \mathrm{bp}$ of the TNF $\alpha$ promoter, and a $3480 \mathrm{bp}$ fragment containing $3455 \mathrm{bp}$ of the CCL2 promoter were fused to the luciferase gene of pGL4.17 and transfected into SW872 cells. After IH stimulation, we measured promoter activities and found that RETN, TNF $\alpha$, and CCL2 promoter activities were significantly decreased by IH in SW872 cells (Figure 5). These results suggested that the gene expression of RETN, TNF $\alpha$, and CCL2 in response to IH was not regulated by transcription. 

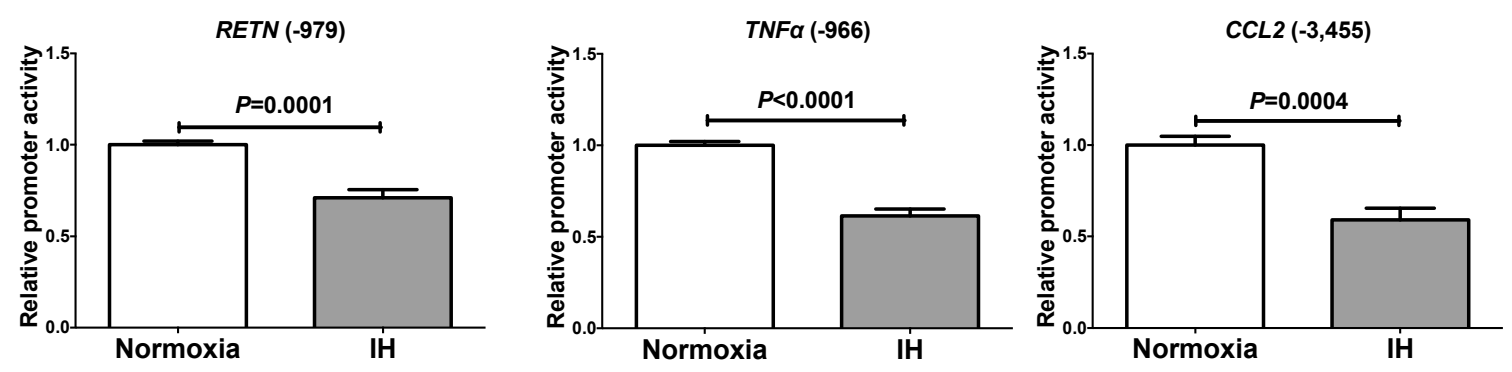

Figure 5. Luciferase assays of promoter activities of RETN, TNF $\alpha$, and CCL2 in SW872 cells. Reporter plasmids prepared by inserting the promoter fragments of RETN (-979 +20), TNF $\alpha(-966 \sim+19)$, and CCL2 (-3455 +25), upstream of a firefly luciferase reporter gene in pGL4.17 vector were transfected into SW872 cells. After cells were exposed either to IH or normoxia for $24 \mathrm{~h}$, the cells were lysed and the promoter activities of RETN, TNF $\alpha$, and CCL2 were measured. All data are represented as the mean \pm SE of the samples $(n=5-6)$. The statistical analyses were performed using Student's $t$-test.

\subsection{The MiR-452 Level Was Significantly Decreased by IH}

We considered a possible explanation that the IH-induced up-regulation of RETN, TNF $\alpha$, and CCL2 was controlled post-transcriptionally. Therefore, we searched targeted miRNA using the MicroRNA.org program (http://www.microrna.org/microrna/home.do), which revealed that RETN, TNF $\alpha$, and CCL2 mRNAs have a potential target sequence for miR-452. There were no other miRNA candidates targeting all three genes. We measured the miR-452 levels of IH-treated cells by RT-PCR and found that the level was significantly lower than that of normoxia-treated cells $(0.02937 \pm 0.09028$ fold vs normoxia, $P=0.0458$ ). The possible reasons as to why the level of miR-452 was decreased by IH include; mRNA levels of some enzymes involved in miRNA biosynthesis/degradation are influenced by $\mathrm{IH}$; and the level of miR-452 was specifically decreased by $\mathrm{IH}$ either via decreased biosynthesis or enhanced degradation. We measured the mRNA levels of ribonuclease type III (DROSHA) and endoribonuclease Dicer (DICER), which are involved in the biosynthesis of miRNAs $[25,26]$ and found that their expression was unchanged by IH (Figure 6). These results suggest that miR-452 plays a key role in post-transcriptional regulation of mRNA levels of RETN, TNF $\alpha$, and CCL2. To investigate whether RETN, TNF $\alpha$, and CCL2 expression in IH is regulated by miR-452, miR-452 mimic and non-specific control RNA (miR-452 mimic NC) were introduced into SW872 cells with IH/normoxia exposure, and the mRNA levels of RETN, TNF $\alpha$, and CCL2 were measured by real-time RT-PCR.
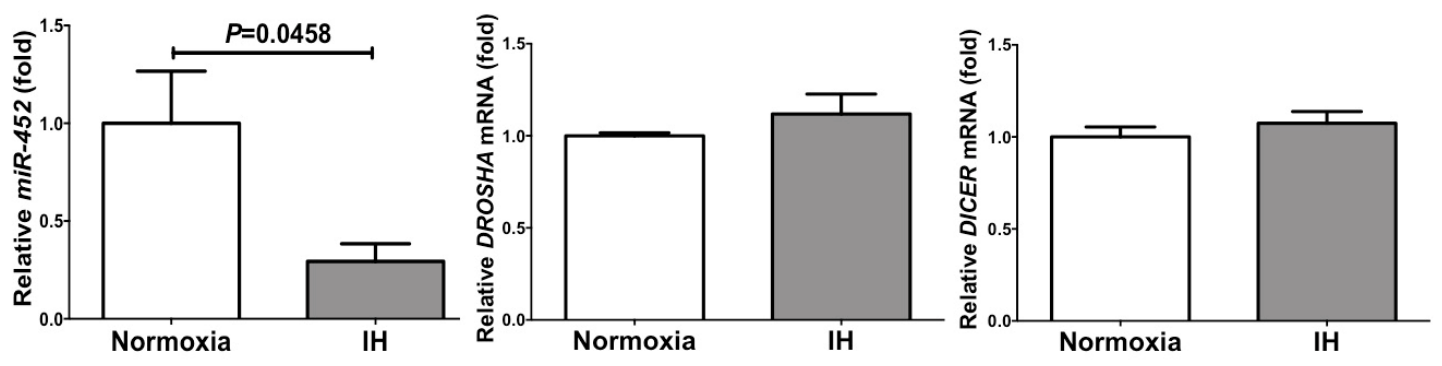

Figure 6. The levels of miR-452, DROSHA mRNA, and DICER mRNA of SW872 cells treated with normoxia or IH for $24 \mathrm{~h}$. The levels of miR-452 and DROSHA and DICER mRNAs were measured by real-time RT-PCR using U6 (for miR-452) and $\beta$-actin (for DROSH and DICER) as an endogenous control. Data are expressed as mean \pm SE for each group $(n=4-6)$. The statistical analyses were performed using Student's $t$-test.

As shown in Figure 7, we found that the IH-induced increases in RETN, TNF $\alpha$ and CCL2 mRNAs were abolished by the introduction of miR-452 mimic but not by miR-452 mimic NC. These findings indicate that IH stress down-regulates the miR-452 level in human adipocytes (Figure 6) and that the levels of RETN, TNF $\alpha$, and CCL2 mRNAs are increased via the miR-452 mediated mechanism. 


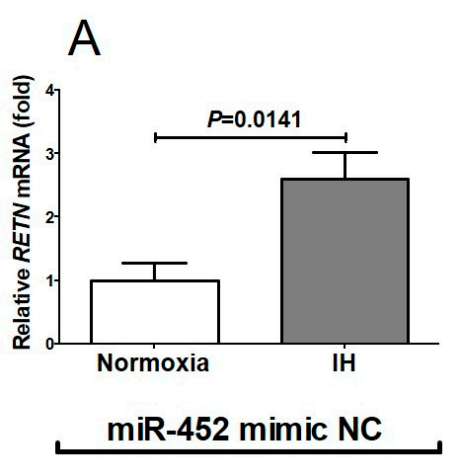

B

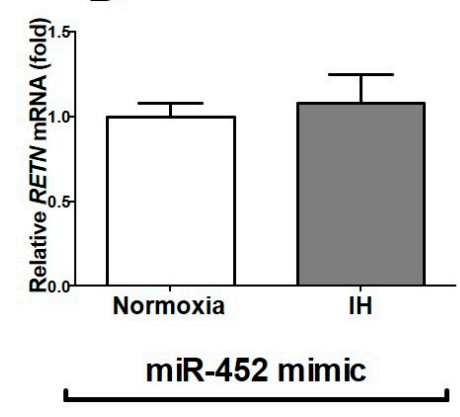

C

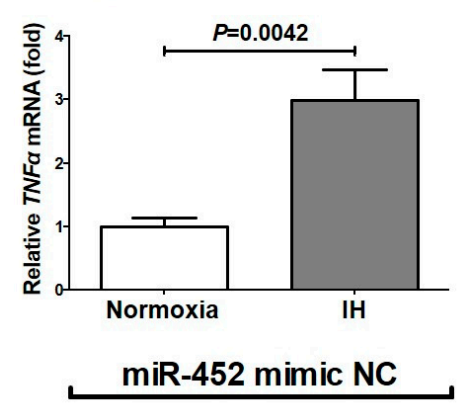

D

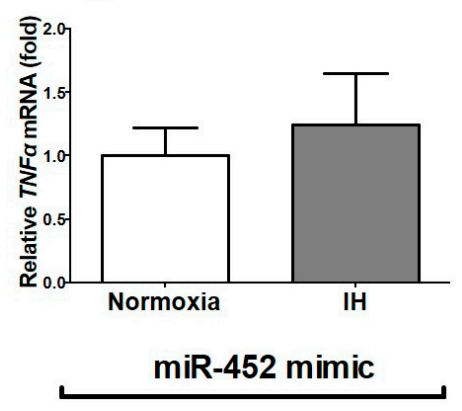

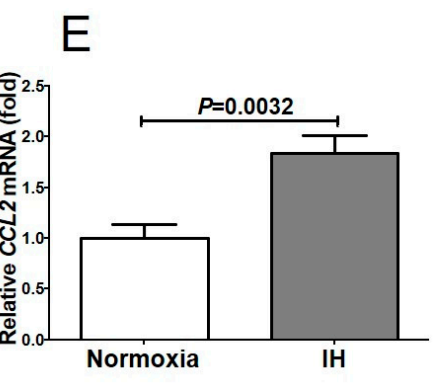

miR-452 mimic NC

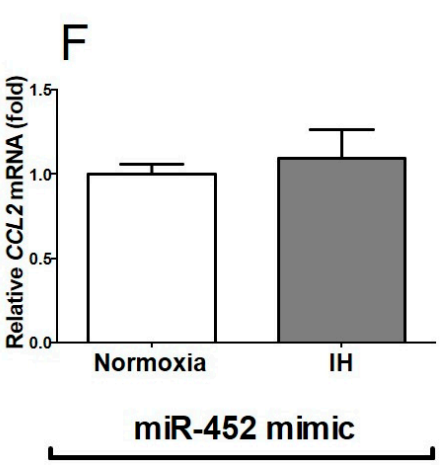

Figure 7. Effects of miR-452 mimic transfection on RETN, TNF $\alpha$, and CCL2 expression. The miR-452 mimic (5'-AACUGUUUGCAGAGGAAACUG-3', 5'-GUUUCCUCUCUGCAAACAGUUUU-3') and non-specific control RNA (miR-452 mimic NC) (5'-UUCUCCGAACGUGUCACGUtt-3', 5'-ACGUGACACGUUCGGAGAAtt-3') were synthesized by Nihon Gene Research Laboratories, Inc. (NGRL; Sendai, Japan) and introduced into SW872 cells using Lipofectamine ${ }^{\circledR}$ RNAiMAX just before $\mathrm{IH} /$ normoxia exposure, and the mRNA levels of RETN, TNF $\alpha$, and CCL2 were measured by real-time RT-PCR, as described in Materials and Methods. The expression of RETN, TNF $\alpha$, and CCL2 mRNA was measured by real-time RT-PCR using $\beta$-actin as an endogenous control. Figure represents (A) RETN mRNA expression in miR-452 mimic NC-introduced cells, (B) RETN mRNA expression in miR-452 mimic-introduced cells, (C) TNF $\alpha$ mRNA expression in miR-452 mimic NC-introduced cells, (D) TNF $\alpha$ mRNA expression in miR-452 mimic-introduced cells, (E) CCL2 mRNA expression in miR-452 mimic NC-introduced cells, and (F) CCL2 mRNA expression in miR-452 mimic-introduced cells. Data are expressed as mean \pm SE for each group $(n=6)$. The statistical analyses were performed using Student's $t$-test.

\section{Discussion}

In this study, we demonstrated that IH exposure induced increases of RETN, TNF $\alpha$, and CCL2 mRNA levels. We further studied that the mechanisms by which IH up-regulates the mRNA levels of adipokines such as RETN, TNF $\alpha$, and CCL2, and found the possibility of post-transcriptional miRNA-regulated mechanisms.

Causal mechanisms mediating the association between $\mathrm{IH}$ and insulin resistance/glucose intolerance are not well established; however, augmented dysfunction/inflammation in adipose tissue might be involved $[9,13,16,17,27,28]$. It is well known that macrophages, which infiltrate into adipose tissue, increase in obese patients, resulting in up-regulation of pro-inflammatory cytokines, such as TNF $\alpha$ and IL-6 [29,30]. However, Thorn et al. reported that adipose tissue is influenced by hypoxia in SAS patients independent of obesity [16]. Some mechanisms linking IH stress and adipose tissue inflammation have been established in 3T3-L1 cells and mouse models $[13,17,27]$. Recently, IH was shown to induce impairment of adipose tissue, leading to various changes in secretion of inflammatory cytokines, called adipokines [16,17,28]. Adipokines, which are bioactive mediators produced and released from adipocytes, play important roles in many physiological and 
pathophysiological processes that contribute to modulate homeostasis, lipid and/or glucose metabolism, blood pressure, inflammation, and atherosclerosis [14,29].

$\mathrm{Ccl} 2$, also referred to as monocyte chemoattractant protein-1, is a key regulator of monocyte infiltration of adipose tissue that plays a central role in the development and maintenance of chronic adipose tissue inflammation and insulin resistance [14,31,32]. In this study, the mRNA levels of $C c l 2$ were significantly increased in the IH condition in mouse 3T3-L1 cells (preadipocytes and adipocytes), and human SW872 cells. TNF $\alpha$ is a pro-inflammatory cytokine mainly produced by monocytes and macrophages. TNF $\alpha$ plays a key role in obesity-related insulin resistance, and increased TNF $\alpha$ levels contribute to impaired glucose homeostasis; however, the role of TNF $\alpha$ as an adipokine in the IH condition has not been fully elucidated [14,31]. In this study, TNF $\alpha$ was produced/secreted from 3T3-L1 adipocytes and SW872 cells in the IH condition. In SAS patients, the elevation of circulating levels of TNF $\alpha$ and CCL2 was reported [33,34]. Some researchers reported that TNF $\alpha$ and CCL2 production in monocytes was up-regulated in SAS patients [35,36], and Tnf $\alpha$ induced the mRNA expression of Ccl2 and IL-6, and attenuated Adip mRNA in 3T3-L1 cells [37]. However, as the expression of Adip mRNA in 3T3-L1 cells was unchanged despite significant increases of $\operatorname{Tnf} \alpha$ and the up-regulation of IL-6 in differentiated 3T3-L1 being small, the up-regulation of adipokine mRNAs (Tnfo, Ccl2, and Retn) could be independently and directly caused by IH. There are few reports about expression of TNF $\alpha$ and CCL2 genes in adipocytes of SAS patients or under the experimental IH condition. From our results, the expression of TNF $\alpha$ and CCL2 was increased in adipocytes and TNF $\alpha$ and CCL2 could act as adipokines contributing to worsening insulin resistance in the IH condition.

Resistin is a pro-inflammatory adipokine and initially named because of its relationship to insulin resistance in rodents [31,38]. Although resistin expression is restricted to adipocytes in mice, it was reported to be produced mainly by macrophages and monocytes in humans. However, Yin et al. reported that resistin was overexpressed in the late stage of adipogenesis of SW872 cells [39]. Recently, resistin has been proposed as a marker of cardiovascular diseases $[40,41]$ and suggested to have a possible link to SAS [42]; however, the relation between insulin resistance and resistin in humans remains unclear. Our results suggested that Retn was produced/secreted from 3T3-L1 adipocytes and SW872 cells in the IH condition. In addition, recent studies indicated that transcription of the Retn gene is induced by pro-inflammatory cytokines such as IL-1, IL-6, and TNF $\alpha$, and that Retn promotes the expression of TNF $\alpha$ and IL-6 by macrophages and monocytes [31]. Considering our results and these findings, RETN may be up-regulated in SAS patients and can lead them to insulin resistance/type 2 diabetes. Adding to $C c l 2$ and $T n f \alpha$, Retn may be one of the adipokines increasing insulin resistance in $\mathrm{IH}$.

Adip is specifically expressed and secreted from adipocytes. Unlike most other adipokines, the level of plasma ADIP in humans is negatively correlated with adiposity, insulin resistance, and type 2 diabetes. A causal role of ADIP in the development of type 2 diabetes, dyslipidemia, and cardiovascular diseases has been established; however, the influence of the IH condition remains unknown $[29,43,44]$. In our study, the mRNA level of ADIP was significantly decreased by IH in SW872 cells, while it was not changed in differentiated or undifferentiated 3T3-L1 cells. One of the reasons that ADIP mRNA levels decrease in SW872 cells is the interaction of ADIP and TNF $\alpha$; that is, in the IH condition, TNF $\alpha$ may suppress ADIP synthesis or activity [14]. IH-induced ADIP decrease may relate to worsening insulin resistance/type 2 diabetes in SAS patients; therefore, further in vivo studies will be needed.

We investigated the mechanisms by which IH up-regulates the mRNA levels of RETN, TNF $\alpha$, and $C C L 2$, and found that the promoter activities of the genes were not increased by $\mathrm{IH}$. This suggests that IH-induced up-regulation of RETN, TNF $\alpha$, and CCL2 mRNAs is regulated in the post-transcriptional step. MiRNAs are small non-coding RNAs, $\sim 22$ nucleotides in length, which modulate gene expression either by translational suppression or degradation of mRNA through binding to the $3^{\prime}$-untranslated regions of target genes in a base-paring manner [45]. They affect the stability of their target mRNAs, resulting in changes in the amount of target mRNA, which is one of the mechanisms of post-transcriptional regulation. Until now, some studies about the role of miR-452 have been performed 
in malignant neoplasms such as pancreatic cancer [46], glioma [47], lung cancer [48,49], and breast cancer [50]. A number of studies have indicated that miRNAs play roles in the regulation of many biological processes (migration, metastasis, cell proliferation, apoptosis, chemosensitivity, etc.) for these various types of tumors. MiRNA studies in type 2 diabetes reported a correlation between circulating miRNAs and type 2 diabetes [51,52]. However, the papers did not indicate an involvement of miR-452 in type 2 diabetes/insulin resistance. In the area of gestational diabetes, miR-452 was reported to be upregulated in human umbilical endothelial cells (HUVEC) from infants of mothers with gestational diabetes [53]. TNF $\alpha$ induced oxidative stress [54] and inflammatory gene expression [55] in HUVEC, and oxidative stress induced up-regulation of CCL2 [56]. In addition, RETN was reported to induce HUVEC dysfunction [57]. The up-regulation of miR-452 in HUVEC from infants of mothers with gestational diabetes might be a defense mechanism to down-regulate TNF $\alpha, C C L 2$, and RETN in HUVEC.

Little is known about the mechanisms regulating adipose tissue inflammation; however, accumulating evidence indicates the importance of the roles of miRNAs in cholesterol and lipid metabolism, and controlling insulin signaling [58]. In the last decade, miRNAs have emerged as key epigenetic regulators in the adipocyte development process and functions [15]. In this study, miR-452 with common target sequence in RETN, TNF $\alpha$, and CCL2 mRNAs could contribute to worsening glucose intolerance [59-61] in the IH-condition by up-regulation of RETN, TNF $\alpha$, and CCL2 mRNAs.

In conclusion, this study revealed that the gene expression of RETN, TNF $\alpha$, and CCL2 were increased via down-regulation of the miR-452 level in IH-treated adipocytes. It is suggested that, in SAS patients, up-regulation of RETN, TNF $\alpha$, and CCL2 may induce a pro-inflammatory phenotype of the adipose tissue, leading to the development of insulin resistance and decreased insulin sensitivity, and miR-452 could play crucial roles in regulation of these gene expressions.

\section{Materials and Methods}

\subsection{Cell Culture}

Mouse 3T3-L1 cells were purchased from the National Institutes of Biomedical Innovation, Health and Nutrition, JCRB Cell Bank (Ibaraki, Japan) and human liposarcoma SW872 cells were purchased from American Type Culture Collection (Manassas, VA, USA). 3T3-L1 and SW872 cells were grown in DMEM (Wako Pure Chemical Industries, Ltd., Osaka, Japan) containing 10\% $(v / v)$ fetal calf serum (FCS), 100 units/mL penicillin G (Wako) and $100 \mu \mathrm{g} / \mathrm{mL}$ streptomycin (Wako) as described [62]. Cells were exposed to either normoxia $\left(21 \% \mathrm{O}_{2}, 5 \% \mathrm{CO}_{2}\right.$, and balanced $\left.\mathrm{N}_{2}\right)$ or intermittent hypoxia (IH: 64 cycles of 5 min sustained hypoxia $\left[1 \% \mathrm{O}_{2}, 5 \% \mathrm{CO}_{2}\right.$, and balanced $\left.\mathrm{N}_{2}\right]$ and $10 \mathrm{~min}$ normoxia) using a custom-designed, computer-controlled incubation chamber attached to an external $\mathrm{O}_{2}-\mathrm{CO}_{2}-\mathrm{N}_{2}$ computer-driven controller $\left(\mathrm{O}_{2}\right.$ programmable control, 9200EX, Wakenyaku Co., Ltd., Kyoto, Japan), as described $[1,11,12,63]$. We used this in vitro model of $\mathrm{IH}$, resulting in fluctuations of pressure of oxygen similar to the IH condition in patients with a severe degree of SAS, repeatedly exposed to severe hypoxemia followed by mild hypoxemia or normoxia (i.e., $\mathrm{IH}$ ) [9]. Kimura and co-workers previously reported that the magnitude of $\mathrm{IH}$ expressed by peripheral oxygen saturation $\left(\mathrm{SpO}_{2}\right)$ fluctuated between $75-98 \%$ and $50-80 \%$ in SAS $[1,64]$, which was almost equivalent to the medium condition in the present study.

\subsection{Differentiation of 3T3-L1 Cells into Adipocyte-Like Cells}

Insulin, methylisobutylxanthine (IBMX) and dexamethasone were purchased from Sigma-Aldrich (St. Louis, MO, USA). To induce adipocyte differentiation, (1) cells were cultured in DMEM medium for 2 days, (2) treated with DMEM medium containing $0.5 \mathrm{mM} \mathrm{IBMX}, 1 \mu \mathrm{M}$ dexamethasone and $10 \mu \mathrm{g} / \mathrm{mL}$ insulin for 3 days, and finally (3) cultured with DMEM medium containing $10 \mu \mathrm{g} / \mathrm{mL}$ insulin for 3 days, as described [65]. The cells were then incubated in fresh DMEM medium for an additional 2 days and fully differentiated adipocyte-like cells were obtained. 


\subsection{RT-PCR}

Total RNA was isolated using a RNA protect cell mini kit (Qiagen, Hilden, Germany) from 3T3-L1 cells (preadipocytes and adipocytes) and SW872 cells, and cDNA was synthesized from total RNA as template using a High Capacity cDNA Reverse Transcription kit (Applied Biosystems, Foster City, CA) as described $[11,12,63,66-71]$. Real-time polymerase chain reaction (PCR) was performed using SYBR ${ }^{\circledR}$ Fast qPCR kit (KAPA Biosystems, Boston, MA) and a Thermal Cycler Dice Real Time System (Takara, Kusatsu, Japan). All the PCR primers were synthesized by Nihon Gene Research Laboratories, Inc. (NGRL; Sendai, Japan), and the primer sequences for each primer set are described in Table 1. PCR was performed with an initial step of $3 \mathrm{~min}$ at $95^{\circ} \mathrm{C}$ followed by 40 cycles of $3 \mathrm{~s}$ at $95^{\circ} \mathrm{C}$ and $20 \mathrm{~s}$ at $60^{\circ} \mathrm{C}$ for $\beta$-actin; 45 cycles of $10 \mathrm{~s}$ at $95^{\circ} \mathrm{C}, 5 \mathrm{~s}$ at $60^{\circ} \mathrm{C}$ and $20 \mathrm{~s}$ at $72{ }^{\circ} \mathrm{C}$ for rat insulinoma gene (Rig)/ribosomal protein S15 (RpS15); 45 cycles of $3 \mathrm{~s}$ at $95^{\circ} \mathrm{C}$ and $20 \mathrm{~s}$ at $62^{\circ} \mathrm{C}$ for $T N F \alpha$ (human) and IL-6 (human); 45 cycles of $3 \mathrm{~s}$ at $95^{\circ} \mathrm{C}$ and $20 \mathrm{~s}$ at $60^{\circ} \mathrm{C}$ for resistin (RETN, human and mouse), C-C motif chemokine ligand 2 (CCL2, human and mouse), adiponectin (ADIP, human and mouse), IL-6 (mouse), leptin (LEP, human and mouse), TNF $\alpha$ (mouse), ribonuclease type III (DROSHA), endoribonuclease Dicer (DICER), and microRNA-452 (miR-452). The mRNA expression levels were normalized to the mRNA level of $\mathrm{Rig} / \mathrm{RpS15}$ in mouse samples or $\beta$-actin in human samples, and the miR-452 level was normalized to the U6 RNA level.

\subsection{Measurement of RETN, TNF $\alpha$ and CCL2 in Culture Medium by Enzyme-Linked Immunosorbent Assay (ELISA)}

Cells were exposed to either normoxia or IH for $24 \mathrm{~h}$, culture medium was collected, and the concentration of RETN, TNF $\alpha$, and CCL2 was measured by using a Human Resistin (RETN) ELISA kit (R\&D Systems, Minneapolis, MN), Human TNF $\alpha$ ELISA kit (Diaclone SAS, Besançon, France) and Human C-C motif chemokine ligand 2 (CCL2) ELISA kit (R\&D Systems) according to the instructions of the suppliers.

\subsection{Construction of Reporter Plasmid and Luciferase Assay}

Reporter plasmids were prepared by inserting the promoter fragments of human RETN $(-979 \sim+20)$, TNF $\alpha(-966 \sim+19)$, and CCL2 (-3455 +25) upstream of a firefly luciferase reporter gene in the pGL4.17 vector (Promega, Madison, WI). The reporter plasmids were transfected into human SW872 adipocytes using Lipofectamine ${ }^{\circledR} 3000$ (Invitrogen, Waltham, MA), as described [68-70], and the cells were exposed to either 64 cycles/24 h of IH, mimicking adipocytes of SAS patients, or normoxia for $24 \mathrm{~h}$. After cells were exposed to $\mathrm{IH}$, the cells were harvested and cell extracts were prepared in extraction buffer (0.1 M potassium phosphate, $\mathrm{pH}$ 7.8/0.2\% Triton X-100; Life Technologies, Carlsbad, CA, USA). To monitor transfection efficiency, pCMV-SPORT- $\beta$ gal plasmid (Life Technologies) was co-transfected in all experiments at a 1:10 dilution. Luciferase activity was measured using a PicaGene luciferase assay system (Toyo-ink, Tokyo, Japan) and was normalized by the $\beta$-galactosidase activity as described previously $[11,12,62,63,67-74]$.

\subsection{MiRNA Extraction, Reverse Transcription, and Real-Time Quantitative PCR}

Total RNA including miRNA was isolated from SW872 cells using the miRNeasy mini kit (Qiagen) according to the manufacturer's instructions. An equal amount of DNase-treated RNA was Poly-A tailed using a Mir- $X^{\mathrm{TM}}$ miRNA first strand synthesis kit (Clontech Laboratories, Inc., Mountain View, CA, USA) according to the manufacturer's protocol. The condition for PCR was $95^{\circ} \mathrm{C}$ for $10 \mathrm{~s}$, followed by 45 cycles of amplification $\left(95^{\circ} \mathrm{C}, 5 \mathrm{~s}, 60^{\circ} \mathrm{C}, 20 \mathrm{~s}\right)$. U6 small nuclear RNA was used as an endogenous control for miRNA as described [11,71,73]. The primers are listed in Table 1. 
Table 1. Primers used for real-time RT-PCR.

\begin{tabular}{|c|c|}
\hline Target mRNA/miR & Primer Sequence \\
\hline \multirow{2}{*}{ Mouse Adip (NM_009065) } & 5'-GGCTCTGTGCTGCTCCATCT-3' \\
\hline & 5'-AGAGTCGTTGACGTTATCTGCATAG-3' \\
\hline \multirow{2}{*}{ Mouse Retn (NM_022984) } & 5'-GTACCCACGGGATGAAGAACC-3' \\
\hline & 5'-GCAGAGCCACAGGAGCAG-3' \\
\hline \multirow{2}{*}{ Mouse IL-6 (NM_031168) } & 5'-ACAACCACGGCCTTCCCTACTT-3' \\
\hline & 5'-CAGGATTTCCCAGCGAACATGTG-3' \\
\hline \multirow{2}{*}{ Mouse TNF $\alpha$ (NM_013693) } & 5'-ССТСССТСТСАTCAGTTCTA-3' \\
\hline & 5'-ACTTGGTGGTTTGCTACGAC-3' \\
\hline \multirow{2}{*}{ Mouse Ccl2 (NM_011333) } & 5'-CCACTCACCTGCTGCTACTCAT -3' \\
\hline & 5'-TGGTGATCCTCTTGTAGCTCTCC -3' \\
\hline \multirow{2}{*}{ Mouse Rig/RpS15 (NM_009091) } & 5'-ACGGCAAGACCTTCAACCAG-3 \\
\hline & 5'-ATGGAGAACTCGCCCAGGTAG-3' \\
\hline \multirow{2}{*}{ Human ADIP (NM_001177800) } & 5'-CATGACCAGGAAACCACGACT -3' \\
\hline & 5'-TGAATGCTGAGCGGTAT -3' \\
\hline \multirow{2}{*}{ Human RETN (NM_020415) } & 5'-ТССТССТССТСССТGTCСТGG-3' \\
\hline & 5'-CAGTGACATGTGGTCTGGGCG -3' \\
\hline \multirow{2}{*}{ Human IL-6 (NM_000600) } & 5'-GGTACATCCTCGACGGCATC-3' \\
\hline & 5'-GCCTCTTTGCTGCTTTCACAC-3' \\
\hline \multirow{2}{*}{ Human TNF $\alpha$ (NM_000594) } & 5'-CTTCTCCTTCCTGATCGTGG-3' \\
\hline & 5'-TCTCAGCTCCACGCCATT-3' \\
\hline \multirow{2}{*}{ Human CCL2 (NM_002982) } & 5'-GTCTCTGCCGCCCTTCTGT-3' \\
\hline & 5'-TTGCATCTGGCTGAGCGAG -3' \\
\hline \multirow{2}{*}{ Human DICER (NM_177438) } & 5'-GAGCTGTCCTATCAGATCAGGG-3' \\
\hline & 5'-ACTTGTTGAGCAACCTGGTTT-3' \\
\hline \multirow{2}{*}{ Human DROSHA (NM_013235) } & 5'-GGCCCGAGAGCCTTTTATAG-3' \\
\hline & 5'-TGCACACGTCTAACTCTTCCAC-3' \\
\hline \multirow{2}{*}{ Human $\beta$-actin (NM_001101) } & 5'-GCGAGAAGATGACCCAGA-3' \\
\hline & 5'-CAGAGGCGTACAGGGATA-3' \\
\hline \multirow{2}{*}{ Human miR-452 (NR_029973) } & 5'-GCGAACTGTTTGCAGAGG-3' \\
\hline & 5'-CAGTGCGTGTCGTGGAGT-3' \\
\hline \multirow{2}{*}{ Human U6 (NR_004394) } & 5'-CTCGCTTCGGCAGCACA-3' \\
\hline & 5'-AACGCTTCACGAATTTGCGT-3' \\
\hline
\end{tabular}

\subsection{MiR-452 Mimic Transfection}

MiR-452 mimic (5'-AACUGUUUGCAGAGGAAACUG-3' ${ }^{\prime}$ ' '-GUUUCCUCUCUGCAAACAGUU UU- $3^{\prime}$ ) and non-specific control RNA (miR-452 mimic NC) (5'-UUCUCCGAACGUGUCACGUtt-3', 5'-ACGUGACACGUUCGGAGAAtt-3') were synthesized by NGRL and introduced into SW872 cells using Lipofectamine ${ }^{\circledR}$ RNAiMAX (Invitrogen) $[11,67-71,73]$ just before IH/normoxia exposure, and the mRNA levels of RETN, TNF- $\alpha$, and CCL2 were measured by real-time RT-PCR, as described $[11,12,63,66-71,73,74]$. 


\subsection{Data Analysis}

Results are expressed as mean \pm SE. Statistical significance was determined by Student's $t$-test using GraphPad Prism software (GraphPad Software, La Jolla, CA, USA).

Author Contributions: T.U., H.O., and S.T. contributed to the study design. T.U., A.I.-H., A.Y., M.M., S.S.-T., R.S., H.O., and S.T. contributed to data collection. T.U., A.I.-H., A.Y., M.M., S.S.-T., R.S., H.O., and S.T. contributed to data analysis. T.U., A.I.-H., A.Y., M.M., S.S.-T., R.S., H.O., M.T., C.O., and S.T. contributed data interpretation. All the authors contributed to revising and approval of manuscript content.

Funding: This work was supported in part by JSPS KAKENHI Grant Number JP18K15067, Grants-in-Aid for Young Scientists from the Ministry of Education, Culture, Sports, Science, and Technology (JSPS), Japan.

Conflicts of Interest: The authors declare no conflict of interest.

\section{Abbreviations}

$\begin{array}{ll}\text { ADIP } & \text { Adiponectin } \\ \text { CCL2 } & \text { C-C motif chemokine ligand 2 } \\ \text { DICER } & \text { Endoribonuclease Dicer } \\ \text { DROSHA } & \text { Ribonuclease type III } \\ \text { ELISA } & \text { Enzyme-linked Immunosorbent assay } \\ \text { FCS } & \text { Fetal calf serum } \\ \text { HUVEC } & \text { Human umbilical endothelial cells } \\ \text { IBMX } & \text { methylisobutylxanthine } \\ \text { IH } & \text { Intermittent hypoxia } \\ \text { IL-6 } & \text { Interleukin-6 } \\ \text { LEP } & \text { Leptin } \\ \text { miRNA } & \text { MicroRNA } \\ \text { RETN } & \text { Resistin } \\ \text { RpS15 } & \text { Ribosomal protein S15 } \\ \text { RT-PCR } & \text { Reverse transcriptase-polymerase chain reaction } \\ \text { SAS } & \text { Sleep apnea syndrome } \\ \text { TNF } \alpha & \text { Tumor necrosis factor- } \alpha\end{array}$

\section{References}

1. Ota, H.; Takasawa, S.; Yamauchi, M.; Yoshikawa, M.; Tomoda, K.; Kimura, H. Intermittent hypoxia in pancreatic beta cells. Pancreat. Disord. Ther. 2015, 5, S5-004.

2. Young, T.; Palta, M.; Dempsey, J.; Skatrud, J.; Weber, S.; Badr, S. The occurrence of sleep-disordered breathing among middle-aged adults. N. Engl. J. Med. 1993, 328, 1230-1235. [CrossRef]

3. Peppard, P.E.; Young, T.; Barnet, J.H.; Palta, M.; Hagen, E.W.; Hla, K.M. Increased prevalence of sleep-disordered breathing in adults. Am. J. Epidemiol. 2013, 177, 1006-1014. [CrossRef] [PubMed]

4. Tasali, E.; Ip, M.S.M. Obstructive sleep apnea and metabolic syndrome: Alterations in glucose metabolism and inflammation. Proc. Am. Thorac. Soc. 2008, 5, 207-217. [CrossRef]

5. Muraki, I.; Tanigawa, T.; Yamagishi, K.; Sakurai, S.; Ohira, T.; Imano, H.; Kitamura, A.; Kiyama, M.; Sato, S.; Shimamoto, T.; et al. CIRCS investigators, Nocturnal intermittent hypoxia and the development of type 2 diabetes: The circulatory risk in communities study (CIRCS). Diabetologia 2010, 53, 481-488. [CrossRef] [PubMed]

6. Kendzerska, T.; Gershon, A.S.; Hawker, G.; Tomlinson, G.; Leung, R.S. Obstructive sleep apnea and incident diabetes. A historical cohort study. Am. J. Respir. Crit. Care Med. 2014, 190, 218-225. [CrossRef]

7. Kent, B.D.; Grote, L.; Ryan, S.; Pépin, J.L.; Bonsignore, M.R.; Tkacova, R.; Saaresranta, T.; Verbraecken, J.; Lévy, P.; Hedner, J.; et al. Diabetes mellitus prevalence and control in sleep-disordered breathing: The European Sleep Apnea Cohort (ESADA) study. Chest 2014, 146, 982-990. [CrossRef]

8. Priou, P.; Le Vaillant, M.; Meslier, N.; Chollet, S.; Pigeanne, T.; Masson, P.; Bizieux-Thaminy, A.; Humeau, M.P.; Goupil, F.; Ducluzeau, P.H.; et al. Association between obstructive sleep apnea severity and glucose control in patients with untreated versus treated diabetes. J. Sleep Res. 2015, 24, 425-431. [CrossRef] [PubMed] 
9. Murphy, A.M.; Thomas, A.; Crinion, S.J.; Kent, B.D.; Tambuwala, M.M.; Fabre, A.; Pepin, J.L.; Roche, H.M.; Arnaud, C.; Ryan, S. Intermittent hypoxia in obstructive sleep apnoea mediates insulin resistance through adipose tissue inflammation. Eur. Respir. J. 2017, 49, 1601731. [CrossRef] [PubMed]

10. Lima, F.F.F.; Mazzotti, D.R.; Tufik, S.; Bittencourt, L. The role inflammatory response genes in obstructive sleep apnea syndrome: A review. Sleep Breath. 2016, 20, 331-338. [CrossRef]

11. Uchiyama, T.; Ota, H.; Itaya-Hironaka, A.; Shobatake, R.; Yamauchi, A.; Sakuramoto-Tsuchida, S.; Makino, M.; Kimura, H.; Takeda, M.; Ohbayashi, C.; et al. Up-regulation of selenoprotein P and HIP/PAP mRNAs in hepatocytes by intermittent hypoxia via down-regulation of miR-203. Biochem. Biophys. Rep. 2017, 11, 130-137. [CrossRef]

12. Shobatake, R.; Takasawa, K.; Ota, H.; Itaya-Hironaka, A.; Yamauchi, A.; Sakuramoto-Tsuchida, S.; Uchiyama, T.; Makino, M.; Sugie, K.; Takasawa, S.; et al. Up-regulation of POMC and CART mRNAs by intermittent hypoxia via GATA transcription factors in human neuronal cells. Int. J. Biochem. Cell Biol. 2018, 95, 100-107. [CrossRef] [PubMed]

13. Gileles-Hillel, A.; Almendros, I.; Khalyfa, A.; Nigdelioglu, R.; Qiao, Z.; Hamanaka, R.B.; Mutlu, G.M.; Akbarpour, M.; Gozal, D. Prolonged exposures to intermittent hypoxia promote visceral white adipose tissue inflammation in a murine model of severe sleep apnea: Effect of normoxic recovery. Sleep 2017, 40, zsw074. [CrossRef] [PubMed]

14. Rabe, K.; Lehrke, M.; Parhofer, K.G.; Broedl, U.C. Adipokines and insulin resistance. Mol. Med. 2008, 14, 741-751. [CrossRef] [PubMed]

15. Maurizi, G.; Babini, L.; Guardia, L.D. Potential role of microRNAs in the regulation of adipocytes liposecretion and adipose tissue physiology. J. Cell. Physiol. 2018, 233, 9077-9086. [CrossRef] [PubMed]

16. Thorn, C.E.; Knight, B.; Pastel, E.; McCulloch, L.J.; Patel, B.; Shore, A.C.; Kos, K. Adipose tissue is influenced by hypoxia of obstructive sleep apnea syndrome independent of obesity. Diabetes Metab. 2017, 43, 240-247. [CrossRef]

17. Weiszenstein, M.; Shimoda, L.A.; Koc, M.; Seda, O.; Polak, J. Inhibition of lipolysis ameliorates diabetic phenotype in a mouse model of obstructive sleep apnea. Am. J. Respir. Cell Mol. Biol. 2016, 55, 299-307. [CrossRef]

18. Rosen, E.D.; Spieglman, B.M. Molecular regulation of adipogenesis. Annu. Rev. Cell Dev. Biol. 2000, 16, 145-171. [CrossRef]

19. Laudes, M. Role of WNT signaling in the determination of human mesenchymal stem cells into preadipocytes. J. Mol. Endocrinol. 2011, 46, R65-R72.

20. Fasshauser, M.; Kkein, J.; Neumann, S.; Eszlinger, M.; Paschke, R. Hormonal regulation of adiponectin gene expression in 3T3-L1 adipocytes. Biochem. Biophys. Res. Commun. 2002, 290, 1084-1089. [CrossRef]

21. Shojima, N.; Sakoda, H.; Ogihara, T.; Fujishiro, M.; Katagiri, H.; Anai, M.; Onishi, Y.; Inukai, K.; Abe, M.; Fukushima, Y.; et al. Hormonal regulation of resistin expression in 3T3-L1 and mouse adipose cells. Diabetes 2002, 51, 1737-1744. [CrossRef]

22. Fasshauer, M.; Klein, J.; Neumann, S.; Eszlinger, M.; Paschke, R. Tumor necrosis factor $\alpha$ is a negative regulator of resistin gene expression and secretion in 3T3-L1 adipocytes. Biochem. Biophys. Res. Commun. 2001, 288, 1027-1031. [CrossRef] [PubMed]

23. Fasshauer, M.; Klein, J.; Lossner, U.; Paschke, R. Interleukin (IL)-6 mRNA expression is stimulated by insulin, isopretenol, tumor necrosis factor alpha, growth hormone, and IL-6 in 3T3-L1 adipocytes. Horm. Metab. Res. 2003, 35, 147-152. [CrossRef]

24. Fasshauser, M.; Kralisch, S.; Klier, M.; Lossner, U.; Bluher, M.; Klein, J.; Paschke, R. Adiponectin gene expression and secretion is inhibited by interleukin-6 in 3T3-L1 adipocytes. Biochem. Biophys. Res. Commun. 2003, 301, 1045-1050. [CrossRef]

25. Francia, S.; Michelini, F.; Sexena, A.; Tang, D.; de Hoon, M.; Anelli, V.; Mione, M.; Carninci, P.; d'Adda di Fagagna, F. Site-specific DICER and DROSHA RNA products control the DNA-damage response. Nature 2012, 488, 231-235. [CrossRef] [PubMed]

26. Zhang, J.; Zhang, X.H.; Wang, C.X.; Liu, B.; Fan, X.S.; Wen, J.J.; Shi, Q.L.; Zhou, X.J. Dysregulation of MicroRNA biosynthesis enzyme Dicer plays an important role in gastric cancer progression. Int. J. Clin. Exp. Pathol. 2014, 7, 1702-1707. 
27. Gozal, D.; Gileles-Hillel, A.; Cortese, R.; Li, Y.; Almendros, I.; Qiao, Z.; Khalyfa, A.A.; Andrade, J.; Khalyfa, A. Visceral white adipose tissue after chronic intermittent and sustained hypoxia in mice. Am. J. Respir. Cell Mol. Biol. 2017, 56, 477-487. [CrossRef] [PubMed]

28. Ryan, S. Adipose tissue inflammation by intermittent hypoxia: Mechanistic link between obstructive sleep apnoea and metabolic dysfunction. J. Physiol. 2017, 595, 2423-2430. [CrossRef]

29. Weisberg, S.P.; McCann, D.; Desai, M.; Rosenbaum, M.; Leibel, R.L.; Ferrante, A.W., Jr. Obesity is associated with macrophage accumulation in adipose tissue. J. Clin. Investig. 2003, 112, 1796-1808. [CrossRef]

30. Tanaka, M.; Itoh, M.; Ogawa, Y.; Suganami, T. Molecular mechanism of obesity-induced 'metabolic' tissue remodeling. J. Diabetes Investig. 2018, 9, 256-261. [CrossRef]

31. Ouchi, N.; Parker, J.L.; Lugus, J.J.; Walsh, K. Adipokines in inflammation and metabolic disease. Nat. Rev. Immunol. 2011, 11, 85-97. [CrossRef]

32. Kulyté, A.; Belarbi, Y.; Lorente-Cebrián, S.; Bambace, C.; Arner, E.; Daub, C.O.; Hedén, P.; Rydén, M.; Mejhert, N.; Arner, P. Additive effects of microRNAs and transcription factors on CCL2 production in human white adipose tissue. Diabetes 2014, 63, 1248-1258. [CrossRef]

33. Ciftci, T.U.; Kokturk, O.; Bukan, N.; Bilgihan, A. The relationship between serum cytokine levels with obesity and obstructive sleep apnea syndrome. Cytokine 2004, 28, 87-91. [CrossRef]

34. Ohga, E.; Tomita, T.; Wada, H.; Yamamoto, H.; Nagase, T.; Ouchi, Y. Effects of obstructive sleep apnea on circulating ICAM-1, IL-8, and MCP-1. J. Appl. Physiol. 2003, 94, 179-184. [CrossRef]

35. Minoguchi, K.; Tazaki, T.; Yokoe, T.; Minoguchi, H.; Watanabe, Y.; Yamamoto, M.; Adachi, M. Elevated production of tumor necrosis factor- $\alpha$ by monocytes in patients with obstructive sleep apnea syndrome. Chest 2004, 126, 1473-1479. [CrossRef]

36. Chuang, L.P.; Chen, N.-H.; Lin, Y.; Ko, W.-S.; Pang, J.-H.S. Increased MCP-1 gene expression in monocytes of severe OSA patients and under intermittent hypoxia. Sleep Breath. 2016, 20, 425-433. [CrossRef]

37. Masunaga, T.; Shiji, A.; Gu, N.; Joo, E.; Li, S.; Adachi, T.; Yamazaki, H.; Yasufa, K.; Kondoh, T.; Tsuda, K. $\gamma$-tocotrienol attenuates TNF- $\alpha$-induced changes in secretion and gene expression of MCP-1, IL-6 and adiponectin in 3T3-L1 adipocytes. Mol. Med. Rep. 2012, 5, 905-909. [CrossRef]

38. Chen, B.H.; Rifai, N.; Song, Y.; Buring, J.E.; Roberts, C.K.; Liu, S.; Manson, J.E. Circulating levels of resistin and risk of type 2 diabetes in men and women: Results from two prospective cohorts. Diabetes Care 2009, 32, 329-334. [CrossRef]

39. Yin, C.; Xiao, Y.; Zhang, W.; Xu, E.; Liu, W.; Yi, X.; Chang, M. DNA microarray analysis of genes differentially expressed in adipocyte differentiation. J. Biosci. 2014, 39, 415-423. [CrossRef] [PubMed]

40. Frankel, D.S.; Vasan, R.S.; D'Agostino Sr, R.B.; Benjamin, E.J.; Levy, D.; Wang, T.J.; Meigs, J.B. Resistin, adiponectin, and risk of heart failure: The Framingham offspring study. J. Am. Coll. Cardiol. 2009, 53, 754-762. [CrossRef] [PubMed]

41. Laurikka, A.; Vuolteenaho, K.; Toikkanen, V.; Rinne, T.; Leppänen, T.; Tarkka, M.; Laurikka, J.; Moilanen, E. Adipocytokine resistin correlates with oxidative stress and myocardial injury in patients undergoing cardiac surgery. Eur. J. Cardiothorac. Surg. 2014, 46, 729-736. [CrossRef] [PubMed]

42. Turnbull, C.D.; Rossi, V.A.; Santer, P.; Schwarz, E.I.; Stradling, J.R.; Petousi, N.; Kohler, M. Effect of OSA on hypoxic and inflammatory markers during CPAP withdrawal: Further evidence from three randomized control trials. Respirology 2017, 22, 793-799. [CrossRef] [PubMed]

43. Yamauchi, T.; Kamon, J.; Ito, Y.; Tsuchida, A.; Yokomizo, T.; Kita, S.; Sugiyama, T.; Miyagishi, M.; Hara, K.; Tsunoda, M.; et al. Cloning of adiponectin receptors that mediate antidiabetic metabolic effects. Nature 2003, 423, 762-769. [CrossRef] [PubMed]

44. Lara-Castro, C.; Fu, Y.; Chung, B.H.; Garvey, W.T. Adiponectin and the metabolic syndrome: Mechanisms mediating risk for metabolic and cardiovascular disease. Curr. Opin. Lipidol. 2007, 18, 263-270. [CrossRef]

45. Esteller, M. Non-coding RNAs in human disease. Nat. Rev. Genet. 2011, 12, 861-874. [CrossRef] [PubMed]

46. Li, H.; Wu, Y.; Li, P. MicroRNA-452 suppresses pancreatic cancer migration and invasion by directly targeting B-cell-specific Moloney murine leukemia virus insertion site 1. Oncol. Lett. 2017, 14, 3235-3242. [CrossRef]

47. Liu, L.; Chen, K.; Wu, J.; Shi, L.; Hu, B.; Cheng, S.; Li, M.; Song, L. Downregulation of miR-452 promotes stem-like traits and tumorigenicity of gliomas. Clin. Cancer Res. 2013, 19, 3429-3438. [CrossRef]

48. He, Z.; Xia, Y.; Pan, C.; Ma, T.; Liu, B.; Wang, J.; Chen, L.; Chen, Y. Up-regulation of miR-452 inhibits metastasis of non-small cell lung cancer by regulating BMI1. Cell. Physiol. Biochem. 2015, 37, 387-398. [CrossRef] 
49. Gan, X.N.; Gan, T.Q.; He, R.Q.; Luo, J.; Tang, R.X.; Wang, H.L.; Zhou, H.; Qing, H.; Ma, J.; Hu, X.H.; et al. Clinical significance of high expression of miR-452-5p in lung squamous cell carcinoma. Oncol. Lett. 2018, 15, 6418-6430. [CrossRef]

50. Li, W.; Li, G.; Fan, Z.; Liu, T. Tumor-suppressive microRNA-452 inhibits migration and invasion of breast cancer cells by directly targeting RAB11A. Oncol. Lett. 2017, 14, 2559-2565. [CrossRef]

51. Ortega, F.J.; Mercader, J.M.; Moreno-Navarrete, J.M.; Rovira, O.; Guerra, E.; Esteve, E.; Xifra, G.; Martínez, C.; Ricart, W.; Rieusset, J.; et al. Profiling of circulating microRNAs reveals common microRNAs linked to Type 2 diabetes that change with insulin sensitization. Diabetes Care 2014, 37, 1375-1383. [CrossRef]

52. He, Y.; Ding, Y.; Liang, B.; Lin, J.; Kim, T.-K.; Yu, H.; Hang, H.; Wang, K. A systemic study of dysregulated microRNA in Type 2 diabetes mellitus. Int. J. Mol. Sci. 2017, 18, 456. [CrossRef]

53. Tryggestad, J.B.; Vishwanath, A.; Jiang, S.; Mallappa, A.; Teague, A.M.; Takahashi, Y.; Thompson, D.M.; Chernausek, S.D. Influence of gestational diabetes mellitus on human umbilical vein endothelial cell miRNA. Clin. Sci. 2016, 130, 1955-1967. [CrossRef]

54. Xia, F.; Wang, C.; Jin, Y.; Liu, Q.; Meng, Q.; Liu, K.; Sun, H. Luteolin protects HUVECs from TNF- $\alpha$-induced oxidative stress and inflammation via its effects on the Nox4/ROS-NF- $\mathrm{kB}$ and MAPK pathways. J. Atheroscler. Thromb. 2014, 21, 768-783. [CrossRef] [PubMed]

55. Da Silva, M.S.; Julien, P.; Bilodeau, J.-F.; Barbier, O.; Rudkowska, I. Trans fatty acids suppress TNF- $\alpha$-induced inflammatory gene expression in endothelial (HUVEC) and hepatocellular carcinoma (HepG2) cells. Lipids 2017, 52, 315-325. [CrossRef]

56. Tumur, Z.; Shimizu, H.; Enomoto, A.; Miyazaki, H.; Niwa, T. Indoxyl sulfate upregulates expression of ICAM-1 and MCP-1 by oxidative stress-induced NFkB activation. Am. J. Nephrol. 2010, 31, 435-441. [CrossRef]

57. Li, Z.; Li, F.; Yan, L.; Li, F.; Li, Y.; Cheng, H.; Fu, Z. Study on the action of resistin-induced human umbilical vein endothelial cell dysfunction. Front. Med. China 2007, 1, 196-199. [CrossRef] [PubMed]

58. Kolfschoten, I.G.M.; Roggli, E.; Nesca, V.; Regazzi, R. Role and therapeutic potential of microRNAs in diabetes. Diabetes Obes. Metab. 2009, 11, 118-129. [CrossRef] [PubMed]

59. Cawthorn, W.P.; Sethi, J.K. TNF- $\alpha$ and adipocyte biology. FEBS Lett. 2008, 582, 117-131. [CrossRef] [PubMed]

60. Sell, H.; Eckel, J. Monocyte chemotactic protein-1 and its role in insulin resistance. Curr. Opin. Lipidol. 2007, 18, 258-262. [CrossRef] [PubMed]

61. Huang, X.; Yang, Z. Resistin's obesity and insulin resistance: The countinuing disconnect between rodents and humans. J. Endocrinol. Investig. 2016, 39, 607-615. [CrossRef] [PubMed]

62. Murakami-Kawaguchi, S.; Takasawa, S.; Onogawa, T.; Nata, K.; Itaya-Hironaka, A.; Sakuramoto-Tsuchida, S.; Yamauchi, A.; Ota, H.; Takeda, M.; Kato, M.; et al. Expression of Ins1 and Ins2 genes in mouse fetal liver. Cell Tissue Res. 2014, 355, 303-314. [CrossRef]

63. Ota, H.; Tamaki, S.; Itaya-Hironaka, A.; Yamauchi, A.; Sakuramoto-Tsuchida, S.; Morioka, T.; Takasawa, S.; Kimura, H. Attenuation of glucose-induced insulin secretion by intermittent hypoxia via down-regulation of CD38. Life Sci. 2012, 90, 206-211. [CrossRef]

64. Niijima, M.; Kimura, H.; Edo, H.; Shinozaki, T.; Kang, J.; Masuyama, S.; Tatsumi, K.; Kuriyama, T. Manifestation of pulmonary hypertension during REM sleep in obstructive sleep apnea syndrome. Am. J. Respir. Crit. Care Med. 1999, 159, 1766-1772. [CrossRef] [PubMed]

65. Reed, B.C.; Lane, M.D. Insulin receptor synthesis and turnover in differentiating 3T3-L1 preadipocytes. Proc. Natl. Acad. Sci. USA 1980, 77, 285-289. [CrossRef]

66. Ota, H.; Itaya-Hironaka, A.; Yamauchi, A.; Sakuramoto-Tsuchida, S.; Miyaoka, T.; Fujimura, T.; Tsujinaka, H.; Yoshimoto, K.; Nakagawara, K.; Tamaki, S.; et al. Pancreatic $\beta$ cell proliferation by intermittent hypoxia via up-regulation of Reg family genes and HGF gene. Life Sci. 2013, 93, 664-672. [CrossRef] [PubMed]

67. Yamauchi, A.; Itaya-Hironaka, A.; Sakuramoto-Tsuchida, S.; Takeda, M.; Yoshimoto, K.; Miyaoka, T.; Fujimura, T.; Tsujinaka, H.; Tsuchida, C.; Ota, H.; et al. Synergistic activations of REG I $\alpha$ and REG IRpromoters by IL-6 and glucocorticoids through JAK/STAT pathway in human pancreatic $\beta$ cells. J. Diabetes Res. 2015, 2015, 173058. [CrossRef] [PubMed]

68. Fujimura, T.; Fujimoto, T.; Itaya-Hironaka, A.; Miyaoka, T.; Yoshimoto, K.; Yamauchi, A.; Sakuramoto-Tsuchida, S.; Kondo, S.; Takeda, M.; Tsujinaka, H.; et al. Interleukin-6/STAT pathway is responsible for the induction of gene expression of REG I $\alpha$, a new auto-antigen in Sjögren's syndrome patients, in salivary duct epithelial cells. Biochem. Biophys. Rep. 2015, 2, 69-74. [CrossRef] [PubMed] 
69. Tsujinaka, H.; Itaya-Hironaka, A.; Yamauchi, A.; Sakuramoto-Tsuchida, S.; Ota, H.; Takeda, M.; Fujimura, T.; Takasawa, S.; Ogata, N. Human retinal pigment epithelial cell proliferation by the combined stimulation of hydroquinone and advanced glycation end-products via up-regulation of VEGF gene. Biochem. Biophys. Rep. 2015, 2, 123-131. [CrossRef]

70. Tsuchida, C.; Sakuramoto-Tsuchida, S.; Takeda, M.; Itaya-Hironaka, A.; Yamauchi, A.; Misu, M.; Shobatake, R.; Uchiyama, T.; Makino, M.; Pujol-Antonell, I.; et al. Expression of REG family genes in human inflammatory bowel diseases and its regulation. Biochem. Biophys. Rep. 2017, 12, 198-205. [CrossRef] [PubMed]

71. Tohma, Y.; Dohi, Y.; Shobatake, R.; Uchiyama, T.; Takeda, M.; Takasawa, S.; Tanaka, Y.; Ohgushi, H. Reg gene expression in periosteum after fracture and its in vitro induction triggered by IL-6. Int. J. Mol. Sci. 2017, 18, 2257. [CrossRef] [PubMed]

72. Nakagawa, K.; Takasawa, S.; Nata, K.; Yamauchi, A.; Itaya-Hironaka, A.; Ota, H.; Yoshimoto, K.; Sakuramoto-Tsuchida, S.; Miyaoka, T.; Takeda, M.; et al. Prevention of Reg I-induced $\beta$-cell apoptosis by IL-6/dexamethasone through activation of HGF gene regulation. Biochim. Biophys. Acta 2013, 1833, 2988-2995. [CrossRef] [PubMed]

73. Takasawa, S.; Tsuchida, C.; Sakuramoto-Tsuchida, S.; Takeda, M.; Itaya-Hironaka, A.; Yamauchi, A.; Misu, M.; Shobatake, R.; Uchiyama, T.; Makino, M.; et al. Expression of human REG family genes in inflammatory bowel diseases and their molecular mechanism. Immunol. Res. 2018, 66, 800-805. [CrossRef] [PubMed]

74. Shobatake, R.; Itaya-Hironaka, A.; Yamauchi, A.; Makino, M.; Sakuramoto-Tsuchida, S.; Uchiyama, T.; Ota, H.; Takahashi, N.; Ueno, S.; Sugie, K.; et al. Intermittent hypoxia up-regulates gene expression of peptide YY (PYY), glucagon-like peptide-1 (GLP-1), and neurotensin (NTS) in enteroendocrine cells. Int. J. Mol. Sci. 2019, 20, 1849. [CrossRef] [PubMed]

(C) 2019 by the authors. Licensee MDPI, Basel, Switzerland. This article is an open access article distributed under the terms and conditions of the Creative Commons Attribution (CC BY) license (http://creativecommons.org/licenses/by/4.0/). 